Portland State University

PDXScholar

1976

\title{
An Investigation of the Performance of Black Children Age 3.6 to 6.0 on Three Subtests of the Illinois Test of Psycholinguistic Abilities
}

George Edward James

Portland State University

Follow this and additional works at: https://pdxscholar.library.pdx.edu/open_access_etds

Part of the Speech Pathology and Audiology Commons Let us know how access to this document benefits you.

Recommended Citation

James, George Edward, "An Investigation of the Performance of Black Children Age 3.6 to 6.0 on Three Subtests of the Illinois Test of Psycholinguistic Abilities" (1976). Dissertations and Theses. Paper 2589. https://doi.org/10.15760/etd.2586

This Thesis is brought to you for free and open access. It has been accepted for inclusion in Dissertations and Theses by an authorized administrator of PDXScholar. Please contact us if we can make this document more accessible: pdxscholar@pdx.edu. 
AN INVESTIGATION OF THE PERFORMANCE OF

BLACK CHILDREN AGE 3.6 TO 6.0 ON THREE SUBTESTS OF

THE ILLINOIS TEST OF PSYCHOLINGUISTIC ABIIITIES

by

George Edward Bush-James

A clinical research and demonstration project submitted in partial fulfillment

of the requirements for the degree of

MASTER OF SCIENCE

in

Speech Communication: Emphasis

in Speech Pathology and Audiology

Portland State University

1976 
THE CLINICAL RESEARCH AND DEMONSTRATION PROJECT OF GEORGE EDWARD

BUSH-JAMES HAS BEEN APPROVED AS PRBSENTED IN OCTOBER, 1976

APPROVED BY

Joan McMahon 


\section{ACKNOWLEDGMENTS}

I wish to express a personal appreciation and deep affection to my friend, advisor and committee chairperson, S. Joan McKahon, for her excellent support and guidance and who also demonstrated that "you can get blood from a rock if you squeeze hard enough." To my committee, Nary Gordon, Dr. Robert Casteel and Dr. Jack Hegrenes, I extend a personal "thank you" for your assistance and patience in hểping me climb my ladder of life.

To my friends in New York I extend a written thank you for the world to read for your support of my endeavors. To my best friend Deb "Two Scoops" Latzke, thanks for a fun time in Crad School in P.O.

To my new friends in Portland, R.P., L.H., M.M., F.N., S.W., C.W., C.H., B.P., K.I., S.R., and many others thanks for your envouragement.

This research project is dedicated to the SEEK Program of CCNY for giving Black students a new start, and to my grandmothers, Sara James and Dorothy Bmery who passed away in my childhood, but their encouragement to "Learn dem books chil!" keeps ringing in my head, it is to them I keep on climbing. 
TABLE OF CONTENTS

PAGE

ACKNOWLEDGMENTS ..........................

IIST OF TABLES

IIST OF FIGURES

CHAPTER

I INTRODUCTION .....................

II REVIEW OF THE IITERATURE . . . . . . . . . . .

Definition of Ianguage ................

Definition of Black Language . . . . . . . .

Rules Governing Language Usage . . . . . . . . .

Black English vs. White English ...........

Methods of Language Assessment ............

Illinois Test of Psycholinguistic Abilities . . .

Problems in Assessing Black Language . . . . . .

Standardization

Ianguage Used in Testing

Test Situation

Race of Examiner

Geographical Location

Ethnic Differences

Summary .........................

III METHODS AND PROCEDURES . . . . . . . . . . . .

Subjects ........................

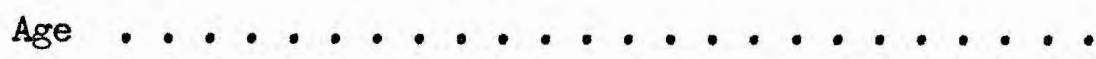


Socioeconomic status .............

Auditory Acuity ...............

Speech Intelligibility ............

Mental Age ................ .

Examiner Bias ...............

Subject Cooperation ............. .

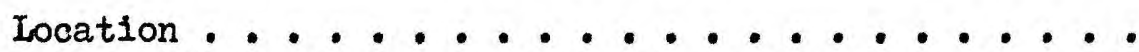

Instrumentation .............

20

Test Administration ..............

Reliability and Validity of Goodenough-Harris Test . .

Data Analysis .............. . .

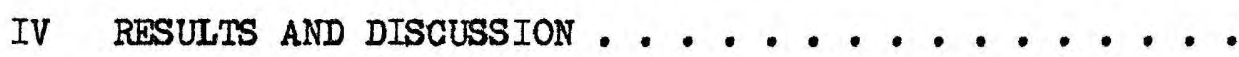

v SUMMARY AND IMPLICATIONS ............

Appendix A: Survey of Language Test's Used in Portland, Oregon, for Language Disorder Diagnosis (June, 1975) .

Appendix B: Linguistic Features of Black Dialect....

Appendix C: Letter and Permission Silp to Parents ...

Appendix $D_{\text {: }}$ Questionnaire for Determining SES ..... 
CHAPTER I

\section{INTRODUCTION}

Researchers whose main goal is to establish normative tables use the statistical methodology known as survey sampling. W1th this type of sampling a researcher examines a finite portion of a population and generalizes about an entire population.

The steps in survey sampling ares choose a group of people in a random procedure; administer the test; transform the raw scores into statistical scores; and apply rigid statistical nethodology so the data will be equifalent to that of the general population. In theory the results nay be accurate, but in actuality one may find discrepancies in what is reported to be standard test performance and what a future testee actually does. This researcher views standardized tables as sinilar to a radio or television signal. The further away one travels from the transmission station, the weaker the signal becomes until it is no longer received.

Researchers in Portland, Oregon (Callahan, 1974; Cole, 1974; Keller, 1975) have reported statistically significant differences between their test population scores and the normative scores of the test instrument used in their studies.

Researchers in Great Britain such as Bernstein (1972), Iavton (1963, 1964) and Poole (1971) reported significant differences anong English speakers at the middle and lower socioeconomic level using 
written and spoken samples of speech within the same geographical location, which lends support to the hypothesis that significant differences in language usage might be found further away from the central test area.

In order to provide for more accurate assessment and better management programs for the communicatively handicapped, it appears that each geographical area should evaluate and establish performance scores on tests which are used within that area. One vital test area that should be considered for this procedure is language, since language is necessary for communication among people.

Sanders (1972) suggested that language assessment should focus attention on four parameters: auditory receptive language; oral expressive language; reading; and writing. Of the four components of language, the aural and oral are natural processes of human beings, while reading and writing are learned behaviors that are dependent upon the aurail-oral components of language.

Numerous language tests have been developed to assess various components of language. Results of a survey taken in June, 1975, by this writer, of seventy-five speech pathologists in the Portland, Oregon, Greater Metropolitan Area, indicated that no one type of test was in common use in Portland (Appendix A). The Peabody P1cture Vocabulary Test (PPVT) (Dunn, 1969), however, appeared to be the most commonly used out of a list of thirty-four reported tests. This was followed by the Daberon School Readiness (Lyons, Danzer, and Gerber, 1972); The Boehm Test of Basic Concepts (Boehm, 1971); The Programmed Conditioning of Language Test (PCLT) (Gray and Ryan, 1973); 
The Northwest Syntax Screening Test (NSST) (Iee, 1970), and The IIlinois Test of Psycholinguistic Abilities (ITPA) (Kirk, Kirk, and McCarthy, 1968). The ITPA appears to be the diagnostic instrument, out of the six most popular, that meets the criteria established by Sanders (1972).

The ITPA is made up of ten subtests with two supplementary subtests that diagnose language performance of a child within the age range of two years to ten years. Three of these subtests, Auditory Reception, Grammatic Closure, and Verbal Expression, provide the speech pathologist with an assessment of a child's aural and oral language performance.

\section{STATEMENT OF PURPOSE}

The purpose of this study was to compare language performance on three subtests of the IIIinois Test of Psycholinguistic Abilitles (ITPA) of a Black population of children ages three years six months through six years in Portland, Oregon, with the standardizing population of the ITPA (Kirk, 1968). These subtests are Auditory Reception, Grammatic Closure, and Verbal Expression.

The null hypotheses tested were:

1) There is no difference in scores on the Auditory Reception subtest of the ITPA between the standardizing tost population and that of Black children ages three years six months through six years in Portland, Oregon.

2) There is no difference in scores on the Crammatic Closure subtest of the ITPA between the standardizing test population and that 
of Black children ages three years $s i x$ months through $s i x$ years in Portland, Oregon.

3) There is no difference in scores on the Verbal Expression subtest of the ITPA between the standardizing test population and that of Black children ages three years $s i x$ months through six years In Portland, Oregon. 
CHAPTER II

REVIEW OF THE LITERATURE

DEFINITION OF IANGUAGE

An important component of interaction between two or more people is language. Ianguage is used to instruct, provide information, give orders, and elicit feelings. Iinguists, psycholinguists, and other researchers have searched and produced numerous opinions in attempts to define language.

Deese (1970), a psycholinguist at John Hopkins University, Indicated that people erroneously equate language with speech because they happen to share a common sound system. Ianguacker (1968) described language in terms of grammar which "is a set of statements saying how language works." Slobin (1971), also a proponent of the grammarian view, wrote: "You can only make sense of the strings of words you hear if you 'know' (In some unconscious sense) the grammar of your language."

Perkins (1971) defined language as "the symbolic formulation of ideas according to semantic and grammatical mules." Pierce (1974) stated, "Ianguage is an arbitrary set of structured vocal symbols." Ryan and Gray (1973) suggested that language be viewed ". . . as the symbolic representation of information which is being transferred from one person to another." 
Berry (1969) stated:

Thanguage is a structured system of arbitrary vocal sounds and sequences of sound which is used in interpersonal communication and which rather exhaustively catalogs the things, events, and processes of human experience. The system inherent in a language derives essentially and primarily from the sequence of articulated, heard sounds in spoken utterences or messages.

After a review of language definitions, for the purpose of this study, language will be defined as follows: an arbitrary set of linguistic rules which govern the way a speaker arranges sounds, words, and their order to express an idea.

\section{DEFINITION OF BLACK LANGUAGE}

Black language recently has become a popular research area, with still much disagreement as to linguistic rules versus cultural patterns. Black language appears to present a particular problem in diagnosis of language disorder among Black children. Confusion exists in determining whether Black language is truly a language disorder or a cultural difference.

Historically, many of the opinions held by educators toward Black language were based on racial biases: sloppy English; inferior English; and the belief that large lips caused poor articulation of English sounds. The present body of literature has produced more objective and scientific descriptions of Black language. Current knowledge suggests that Black language is a systematic language. According to Williams (1974), Black English is a systematic language in its own right and not just an approximation of standard English. Seymour (1971) another supporter of the systematic view, 
stated that Black language is ". . not just sloppy talk but a dialect with a form and structure of its own."

Baratz (1972) reported Black language to be ". . . a well ordered system with a predictable sound pattern, grammatical structure, and vocabulary . . Hopper and Naremore (1973) in their review of the literature on Black language, concluded, "It is as highly structured and rule governed as standard English."

Taylor (1972) hypothesized Black English to be a creole form of standard English. Bailey (in Stewart 1972) also stated, "Black language is a derivation of creole English."

As is true of the preceeding definition of language, due to the varied and divergent opinions, a concrete definition of Black language is yet to be written.

The general concensus among psycholinguists, linguists, and other researchers is that Black language is a language system used by a specific ethnic group, Blacks, based on a variation of the English language system.

RUIES GOVERNING LANGUAGE USAGE

Before a child can initiate communication with others, Reeker (1971) suggested that he or she has to learn three important factors of language:

a) the relationship between a subset of sounds he can produce and an arbitrary vocabulary;

b) a set of arbitrary rules in order to arrange the vocabulary items; 
c) how these structures are used in human communication. In other words, the child has to learn rules of: 1) phonology 2) morphology; 3) syntax; 4) semantics. Another set of rules that can be added to this Iist, according to Hopper and Narenore (1973), is pragmatics.

Hopper and Naremore (1973) present these rules in order of their acquisition. The first set of rules that is acquired is phonology. These rules state how sounds are made and in which order they can be combined. The second set of rules is morphology. Morphology, according to Gordon (1975):

is the study of patterns of word formation, including inflections, and derivational forms, i.e. grammar of language, or rules for building words with regard to tense, case, number, and person.

When the child has established a sufficient body of morephemes, he or she begins to employ a third set of rules for putting them in order to form a sentence. These rules are called syntax. In order for the child to produce adult sentences he or she has to employ another set of rules known as semantics. Semantics are the rules that give meaning to words. The fifth set of rules, pragmaties, is concerned with how words are used in relation to the rules of grammer, phonology, morphology, syntax and semantics.

Black Bnglish vs. White Fnglish

Within the past decade or so, research has produced numerous opinions and theories about Black langrage in relation to standard English. Two of the most controversial theories in this area are the Deficit theory and the Difference theory. 
The Deficit theory is summarized by Peskin (1973) as "The belief that children of lower socioeconomic status, more speciflcally black children--have defective conceptual and communicative systems. ." This theory has been supported by the research of Bereiter (1965), Engleman (1972), and Jensen (1973b).

The Difference theory, as stated by MeNeil (1974) is that "Lowerclass children learn dialects that are simply different from those of middle class." This theory has been supported by the research of Baratz (1969), Dobzhansky (1973), and Hopper and Naremore (1973).

Over the years, research has been re-directed from consideration of Black language as "inferior," to a more objective consideration of how Black language varies from the standard Bnglish format.

Researchers (Baratz, 1969, 1972; Labov, 1972; Stewart, 1972; Taylor, 1972; Williams, 1972; Hopper and Naremore, 1973) have begun to investigate Black language in terms of how the Black speaker employs the rules of standard Inglish to construct sentenees for communication. These researchers have gathered numerous samples from various regions and analyzed them in relation to the five basic mules of language mentioned previously. The by-product, thus far, of these analyses have been detailed descriptions of some of the lingulstic features of Black language. Some of these features are 1 1) reduction of consonant clusters; 2) reduction of $/ x /$ and $/ 1 / 3$ ) absence of possessives; 4) use of double negatives; and 5) lack of subject verb agreement. For a more indepth description, see Appendix $B_{\text {. }}$ 


\section{METHODS OF LANGUAGE ASSESSMENT}

Prior to the establishment and implementation of a language management program for the communicativelyhhandicapped child, an assessment of his or her strengths and weaknesses in language should have been performed. Traditional methods of language assessment have been concerned with three areas: 1) graph1c;2) auditory (receptive); and 3) oral (expressive).

Some of the techniques of graphic evaluation have been to analyze a sample of writing from the student, reading comprehension tests, (which examines the child's ability to read and answer questions), and the "cloze" technique which requires the child to fill in the missing blanks in written materlal.

The aural and oral aspects of language are the most noticeable in human interaction because they are used more frequently than reading or writing. When there is difficulty with either aural or oral language, there is usually a problem in communication.

The auditory or receptive assessment of a child's language ability has been measured by such tests as the Peabody Picture Vocabulary Test (Dunn, 1969); the receptive portion of the Northwest Syntax Screening Test (Iee, 1970); and the Assessment of Children's Language Comprehension (Foster, et al, 1972).

The oral, or expressive, component of language has had such measures as: 1) the Mean Length of Response (MLR); 2) Analysis of a child's speech in relation to peers and adults; 3) Sentence repetition both meaningful and amphigory; 4) Vocabulary sections of the Stanford- 
Binet and Wechsler intelligence scales; 5) Carrow's Blicited Language Inventory (Carrow, 1974); 6) The expressive portion of the Northwest Syntax Screening Test (Lee, 1970); and, 7) The Illinois Test of Psycholinguistic Abilities (ITPA) (Kirk, Kirk and McCarthy, 1968).

\section{ILIINOIS TEST OF PSYCHOLINGUIST ABILITIES (ITPA)}

As stated previously, Sanders (1972) suggested that language be assessed on four parameters: 1) oral; 2) aural; 3) reading and, 4) writing. Of all the tests listed previously, only the ITPA is able to meet the criteria established by Sanders.

The IPTA was first published in 1961 by Kirk and McCarthy to diagnose individual psycholinguistic performance and to determine the effects of management on such children. The ITPA is divided into twelve standardized subtests.

In testing for disorders in the aural-oral component of language, three subtests fulfill this need: Auditory Reception, assessing the child's ability to comprehend the auditory stimuli received; Verbal Expression, assessing the child's ability to express his/her ideas; and, Grammatic Closure, assessing the child's ability to handle syntax and grammatic inflections.

An evaluation of the ITPA was done by Severson and Guest (1972) and they stated that the most extended information obtained on the ITPA with Black children is from Tennessee. According to this article when Black subjects were compared to the standardization population, it emonstrated that Blacks obtained higher scores on the "Auditory-Vocal 
Sequential and Visual-Motor association tasks, while their low scores where in Auditory-Vocal Automatic tasks." In addition, during the standardizing process only 42 Black children were involved, which makes accurate evaluation of Black performance difficult. Within this sample of Blacks only 11 children were within the age range of three years six months to six years, with no Black children in the four to five year age range.

Cochrane (1970) states the ITPA to be a good language test beoause:

it breaks down the ways in which a child acquires language into areas of visual competence, auditory competence and expressive competence that it can suggest to the remedial therapist some positive and practical pathways for approaching the child's learning problem.

\section{PROBLEMS IN ASSESSING BLACK LANGUAGE}

Standardization

An important aspect to consider when using a language test is where the standardization was performed and what type of types of population and age ranges were used in the standardization process. Out of the five popular tests reported, two of the tests, Daberon and PCLT have no standardized norms. The PPVT, NSST, and Boehm standardizing population were predominantly from the upper middle class white population located in one specific geographical area. The ITPA included all races, even though it was not representative of the U.S. population, and income levels in their standardization procedures. The ITPA also utilized five different counties, four in Illinois and one in Wisconsin, in their standardization procedures thereby increasing the statistical 
probability of obtaining a sample representative of the general population.

\section{Language Used In Testing}

When the task of evaluating and assessing a Black child's language ability is encountered, a test must be used that has been written for as well as standardized on the white population. Researchers (Baratz, 1969, 1972; Labov, 1972; Williams, 1972; Hopper and Naremore, 1973; Callahan, 1974; Cole, 1974; Keller, 1975) have investigated the linguistic content of several tests in relation to the Black child's language system. They concluded that the Black child is more familiar and comfortable with his own language system and when the standard English system is used as the stimulus, it places the child at a disadvantage causing him or her to perform poorly on the test.

\section{Test Situation}

Investigation has also been conducted on the test structure and its effect on the assessment and evaluation of the Black child.

Samuda (1975) felt that the test situations are highly structured and consequently foreign to the Black child, thereby inhibiting the child's performance.

Keller (1975) also supports this view that one should consider the formality of the test situation which inhibits the child's language output. She suggested that it is "best to have an informal testing situation, thereby encouraging a more accurate language sample." 
Race of the Examiner

Another problem that has been investigated in assessing Black students is subject-examiner interaction. Baratz (1967) reported that the level of anxiety in Black subjects was elevated when confronted by a white examiner. Severson and Guest (1972) reported that Black children tended to be less verbal in the presence of a white examiner.

Callahan (1974) hypothesized that when the Black child is confronted by the white examiner "the black child would be aware that black English would not be the acceptable mode of response. . ." Katz (1966) in his research suggested that "the race of the examiner affects not only the arousal of Negro subjects, but serves as a cue for the tendency to compete or to avoid competition in evaluative situations." Phillips (1966) conducted an experiment employing complex tasks with both Black and white examiners. She stated "this interaction between tace of examiner and task complexity causes Negro subjects to perform better for Negro examiners on complex tasks due to the interfering effects of anxiety associated with white examiners."

Rutsnick and Koenigsknecht (1975) conducted research with Black and White speech and language clinicians in administering the Goodenough Drawing Test. Although their overall test results "were not statistically significant" they did suggest that Black pre-schoolers "displayed a supertor drawing performance when they were tested by black rather than white speech and language clinicians." 
Geographical Location

It was stated in chapter one that researchers in Portland, Oregon, have reported statistically significant differences between their test population scores and the normative scores of the test instrument used in their studies.

Evard (1974) questioned "whether a test developed for one population is valid when administered to another." Researchers (Baratz, 1969, 1972; Labov, 1972; Williams, 1972; Callahan, 1974; Cole, 1974; Evard, 1974; Keller, 1975) have investigated the reliability and validity of standardized tests in different geographical locations. Cole (1974) performed a comparison of responses between his subjects in Portland, Oregon, to those of Kresheck and Nicolosi in Rockford, Illinois, on the Peabody Plcture Vocabulary Test. He reported that his subjects did not conform to the research of Kresheck and Nicolosi.

It can be inferred from the research on this topic that in order to provide a more accurate assessment and better rehabilitation programs that regional or local norms should be established.

\section{Ethnic Differences}

Researchers, such as Wolfram (1972) and Callahan (1974), have begun to examine the differences in results of Blacks on standardized tests. Wolfram (1972) felt that "using norms established on one ethnic group to judge others is not a legitimate practice."

Callahan (1974) compared her results of Black children on the Northwest Syntax Screening Test (NSST) with those of Wolfram and Lee. 
She concluded that "over 50 percent of her test population mean scores were below the 10th percentile" when compared to Iee's normative data that was used to establish the NSST.

It appears, from the results of the Callahan (1974) study, that to employ language tests that have been standardized on whites from a different geographical region, increases the probability of obtaining lower scores from Blaciks due to location as well as race.

\section{SUMMARY}

The review of the literature suggests a need to test enough Black children in different parts of. the country to establish criteria for judging the adequacy of Black language. Once this data has been gathered, analyzed and put into language tables, speech and language clinicians along with other educators could then begin to assess their Black population's language ability against scores that were standardized on Blacks in their own geographical location instead of scores standardized on whites in other parts of the country.

A purpose of this study was to help establish language tables on three subtests of the IIIinois Test of Psycholinguistic Abilities for a Black population of children ages three years six months through six years in Portland, Oregon. It was a goal of this study to have this data serve as a beginning standard against which to measure the Portland Black child's language ability. 
CHAPTER III

METHODS AND PROCEDURES

SUBJECTS

Subjects were forty Black children, 22 males and 18 females, six to eight subjects at each age level, at six month intervals from three years six months to six years, randomly selected from two day care centers and one elementary school in Portland, Oregon.

All subjects were screened to determine their race, age, auditory. acuity, speech intelligibility, mental age, subject cooperation and socioeconomic status. Letters requesting permission for subject participation in this study (Appendix C) were enclosed with a questionnaire (Appendix D) to determine socioeconomic status (SES).

\section{VARIABLES}

Age

The age range of the subjects were from three years six months to six years resulting in six groups at each six month interval. A plus or minus two month allowance at each age level was allowed in order to obtain subjects. Age was determined by subtracting a child's birthdate from the test date. 
$\underline{\text { Race }}$

All children conformed to the racial criteria established by the Portland Pablic Schools which indicates that if a child had two Black parents or one Black parent and the other of a different race, the child is considered Black.

\section{Soctoeconomic Status (SES)}

SES was determined by three factors: 1) occupation of head of household; 2) amount of education of head of household; and 3) income of head of household. The factors were then taken and converted to SES Scores using the U.S. Bureau of Census Working Paper Number Fifteen, Methodology and Scoring SES (1960). Classification of SES resulted in numerical scores ranging from 96, high, to 18 , low. These scores were labeled as 82-96 (high), 65-81 (middle), and 64-18 (low).

\section{Auditory Acuity}

Auditory acuity was determined by informal screening. The subject was placed with his or her back toward the examiner, six to eight feet away. The subject was then asked to repeat four sentences: "Put your hand up." "Tell me your name." "Clap your hands." "Sit down in the chair." The investigator used less intensity than a normal speaking voice. Any subject failing to respond correctly to one or more sentences was excluded from the study.

\section{Speech Intelligibility}

Speech intelligibility was determined from responses to questions on the drawing task and examinerfehild interaction with toys and books utilized as stimulus material when needed. All children passed the 
speech intelligibility screening test.

Mental Age

The Goodenough-Harris Drawing Test (GHDT) was used to assess mental age. Mental Age in this study was used as a classification tool to assign subjects to groups for analysis, rather than to exclude a subject from participating in the study.

Samuda (1975), in discussing alternatives to traditional standardIzed tests, cites Anastasi (1968) who reported the Goddenough-Hamis Drawing Test has "been administered widely in clinics as a supplement to the Stanford-Binet and other verbal scales."

Ratusnik and Koenigsknecht (1975) using the GHDT in a bi-racial testing situation concluded that "the drawing task seemed to provide a fair estimation of preschoolers mental maturity levels in those groups studied." The study also indicated that when the client and clinician are of the same race, the child will "perform better."

\section{Examiner Bias}

Research (Ratusnik and Koenigsknecht, 1975; Samuda, 1975, Baratz, 1969; Katz, 1966; Phill1ps, 1966) has suggested in interracial test situations a white examiner might influence the output of the Black examinee and increase the stress level. To reduce the stress factor and allow for maximum potential output from the Black subjects, the examiner conducting the test was also Black.

\section{Subject Cooperation}

Subject cooperation was determined from ease of elicitation of 
responses to the screening tasks and compliance to tasks without more than gentle coaxing, e.g., "wasn't that fun?," and "let's do this." If more than gentle coaxing was required, the child was not included in this study.

\section{Iocation}

Location of the testing was dependent upon the availability of the parent to provide transportation. Since all parents of the subjects were working during the school hours, all children were tested at their day care center of school.

Testing was conducted at a table in an empty classroom located in a quiet part of the building free from interruptions. The examiner sat across from the child, whose back was placed toward the window to minimize distractions.

\section{INSTRUMENTATION}

The IMPA (Kirk, Kirk and McCarthy, 1968) is a diagnostic test based on a psycholinguistic model which:

- . attempts to relate those functions whereby the intentions of one individual are transmitted (verbally or non-verbally) to another individual and, reciprocally, functions where by the environment or intentions of another individual are received and interpreted.

It is composed of ten subtests: 1) Auditory Reception; 2) Visual Reception; 3) Visual Sequential Memory; 4) Auditory Association; 5) Auditory Sequential Memory; 6) Visual Association; 7) Visual Closure; 8) Verbal Expression; 9) Grammatic Closure; and 10) Manual Expression. The new revised edition includes two supplementary tests, 
Auditory Closure, and Sound Blending.

From the above subtests three subtests were selected for administration to subjects in this study, 1) Auditory Reception which assesses the ability of the child to derive meaning from verbally presented material; 2) Grammatic Closure which assesses the child's ability to fill in the correct grammatical form when missing; and 3) Verbal Expression which assesses the child's ability to express his or her own concepts verbally.

The ITPA, according to Severson and Guest (1972), "has certainly provided now information about learning disabilities." They felt, despite sone inadequacies in standardizing the test for a Black population, thestest constructors are constantly revising the ITPA and "the ITPA appears to be the only test that has been standardized to sample the cognitive ability for language and langrage usage."

\section{Test Administration}

Test administration, which included screening and data collection, required approximately twenty minutes. Screening began with an auditory acuity task followed by elicitation of a langrage sample for Intell1gibility and terminated with the GHDT. Following the screening and determining of subject cooperation, the three subtests of the ITPA were adininistered.

Scoring

Scoring of the three subtests and the drawing task was conducted according to the instructions given in the respective manuals. 
Reliability and Validity of GHDT

Reliability and validity of the examiner's scores on the GHDT were cross checked by an experienced professor, a Speech Pathologist, (ASHA CCC-Sp.) at Portland State University in the Speech and Hearing Sciences Program, with a broad background in psychometric testing. A random sample of GHDT were selected and scored by the professor. A Pearson $\underline{I}$ was used to determine inter-judge reliability and validity.

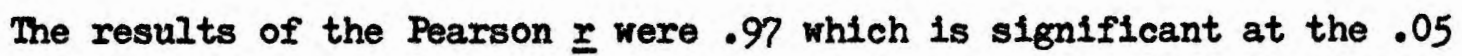
level of significance. A t-test was employed to determine the signi-

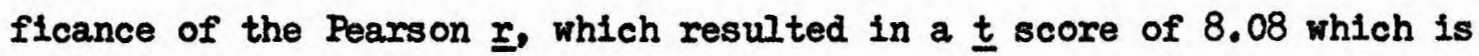
statistically significant at the .05 level and beyond.

\section{DATA ANALYSIS}

Forty chlldren from Kirk's standardizing population were matched chronologically to the forty children in Portland, Oregon. To investigate any statistical differences in the chronological ages between the two samples, t-tests were used.

A two-factor analysis of variance (2-ANOVA) was employed to test the null hypotheses. To investigate the Portland sample performances on the various subtests by socioeconomic status, t-tests were used. 
CHAPTER IV

\section{RESULTS AND DISCUSSION}

\section{RESULTS}

\section{Description of Samples}

Before applying statistical analysis to the data, procedures were employed to insure that both samples were the same in respect to chronological age and mental age.

An attempt was made to match forty children from Kirk's standardizing population with forty children from Portland, Oregon, on chronological age. The results of this procedure yielded twenty-seven exact matches and thirteen approximated matches plus or minus one to three months. Since a total matched sample was not achieved, t-tests were applied and revealed no statistically signiflcant differences between the two means of each age group at the .05 level of significance (Table I).

\section{Table I}

RESULIS OF $t$-TESTS OF CHRONOLOGICAL AGES FOR KIRK'S SAMPLE AND JAMES' SAMPLE

$$
\begin{gathered}
\text { Age Group } \\
\begin{array}{|c|c|c|c|c|c|}
\hline 3.6 & 4.0 & 4.6 & 5.0 & 5.6 & 6.0 \\
\hline 0^{*} & 0 * & 1.40^{*} & 1.28^{*} & 1.31 * & 1.11 * \\
\hline
\end{array} \\
\hline \text { *N.S. = Not significant at .05 level of significance }
\end{gathered}
$$


A two-factor analysis of variance (2-ANOVA) was conducted on the mental ages (M.A.) of the two samples. The results indicated that performance on the ITPA subtests varied with mental age levels at the .05 level, however, no statistically significant variation was found due to location and interaction of unknown variables outside of age and location. Hence, the null hypothesis, there is no difference in mental ages between the standardizing test population and that of Black children ages three years six months through six years in Portland, Oregon, was accepted (Table II).

Table II

RESULTS OF 2-ANOVA FOR M.A., LOCATION AND RACE

\begin{tabular}{|l|r|r|r|c|}
\hline \multicolumn{1}{|c|}{ Source } & \multicolumn{1}{c}{ ss } & \multicolumn{1}{c}{ df } & \multicolumn{1}{c}{ MS } & \multicolumn{1}{c|}{ P } \\
\hline Mental Age & 9554.73 & 5 & 1.910 .94 & $13.33^{*}$ \\
Location & 42.04 & 1 & 42.04 & $.293^{* *}$ \\
Interaction & 637.82 & 5 & 127.56 & $.889^{* *}$ \\
Ihror & 9748.21 & 68 & 143.35 & - \\
\hline
\end{tabular}

$*_{p}<.05$, significant $* * p>.05$, non-significant

\section{Results of SES Analysis}

For further information, analysis based on socioeconomic status (SES) within the Portland sample was conducted using t-tests for comparison of the means of the ITPA subtests scores.

Thus, the following additional null hypotheses were tested relative to the SES: there is no difference in scores obtained by 1) High versus Low SES; 2) High versus Middle SES; and 3) Middle versus Low SES on the three subtests of the ITPA. No statistically significant 
differences were found anong SES groups on the Auditory Reception and Verbal Expression subtests and also between the High versus Middle SES and Middle versus Low SES on the Grammatic Closure subtest. Therefore, the null hypotheses were accepted for these groups. A comparison between High versus Low SBS was found on the Grammatic Closure subtest resulting in a t-test that was statistically significant at $p<.05$. cconsequently, the null hypothesis was rejected. Table III is a delination of the SES subtests interaction and figure one indicates the distribution of subjects by SES status.

Pable III

ANALYSIS OF SES AND SUBTESTS INTERACTION FOR SAMPLB GROUP

\begin{tabular}{|l|l|l|l|}
\hline SES Range & $\begin{array}{l}\text { Aud. Recept. } \\
\text { Raw Scores }\end{array}$ & $\begin{array}{l}\text { Gram. Closure } \\
\text { Raw Scores }\end{array}$ & $\begin{array}{l}\text { Verbal Exp. } \\
\text { Raw Scores }\end{array}$ \\
\hline 82-96, High & $\bar{x}=18.0$ & $\bar{x}=10.08$ & $\bar{x}=9.50$ \\
$N=12$ & $6=4.20$ & $6=5.26$ & $6=3.03$ \\
\hline $\begin{array}{l}65-81 \\
\text { middie }\end{array}$ & $\bar{x}=17.0$ & $\bar{x}=9.12$ & $\bar{x}=8.53$ \\
$N=17$ & $6=6.16$ & $6=6.14$ & $6=5.04$ \\
\hline $18-64$, Iow & $\bar{x}=14.3$ & $\bar{x}=6.66$ & $\bar{x}=8.80$ \\
N $=10$ & $6=8.88$ & $6=2.54$ & $6=2.86$ \\
\hline
\end{tabular}


FIGURE 1

SOCIOECONOMIC STATUS

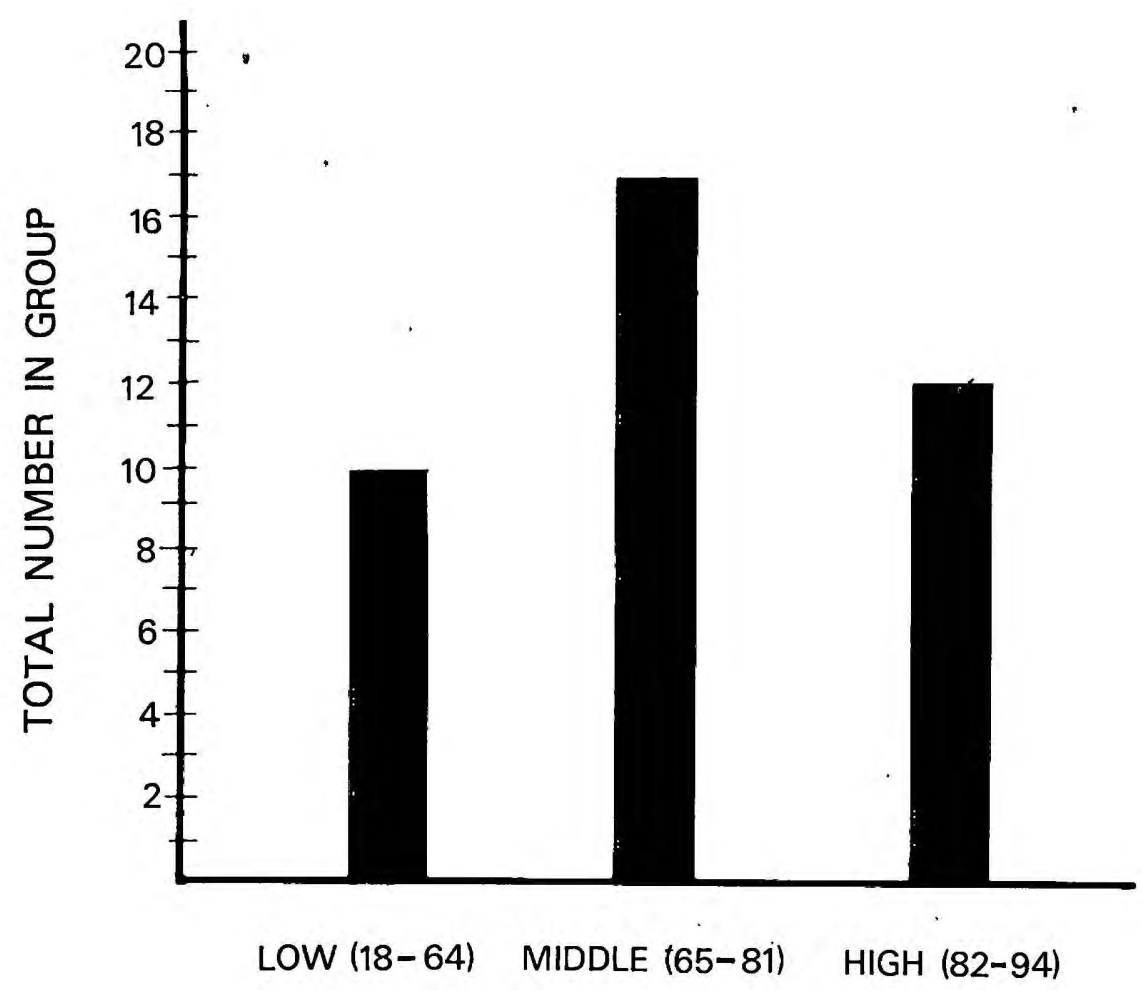


The Subtests

One null hypothesis states there is no statistically significant difference in scores on the Auditory Reception subtest of the ITPA between the standardizing test population and that of Black children ages three years six months through six years in Portland, Oregon. The results of the 2-ANOVA indicated a sstatistically significant factor at the .05 level for age; however, no statistical differences were found for the variables of location or interaction. Therefore, the null was accepted for this subtest (Table IV).

\section{Table IV}

2-ANOVA FOR AUDITORY RECEPTION FOR KIRK'S SAMPLE AND JAMES' SAMPLE

\begin{tabular}{l|r|r|r|r|}
\hline \multicolumn{2}{c|}{ Source } & \multicolumn{1}{c}{ ss } & \multicolumn{1}{c}{ df } & MS \\
\hline Chron. Age & $1,155.85$ & 5 & 231.17 & $6.10^{*}$ \\
Location & 52.81 & 1 & 52.81 & $1.39^{* *}$ \\
Interaction & 185.34 & 5 & 37.06 & $.97^{* *}$ \\
Brror & $2,573.99$ & 68 & 37.85 & \\
\hline
\end{tabular}

$$
*_{p}<.05, \text { significant } \quad *_{*}^{*}>05 \text {, non significant }
$$

The second null hypothesis states there is no statistically significant differences would be found on the Grammatic Closure subtest of the ITPA between the standardizing test population and that of Black children ages three years six months through six years in Portland, Oregon. The results of the 2-ANOVA indicated a statistically significant difference at the .05 level on all variables, hence the null 
hypothesis can be rejected for this subtest (Table V).

\section{Table V}

2-ANOVA FOR GRAMMATICAL CLOSURE SUBTEST

FOR KIRK'S SAMPLEE AND JAMES' SAMPLE

\begin{tabular}{l|r|r|r|r|}
\hline \multicolumn{1}{|c|}{ Source } & \multicolumn{1}{c}{ df } & \multicolumn{1}{c|}{ MS } \\
\hline Chron. Age & 722.27 & 5 & 144.45 & F \\
Location & 78.01 & 1 & 78.01 & $9.45^{*}$ \\
Interaction & 225.66 & 5 & 45.13 & $5.10^{*}$ \\
Drror & $1,038.95$ & 68 & 15.27 & $2.95^{*}$ \\
\hline
\end{tabular}

${ }^{*} p<.05$

The third null hypothesis states there is no statistically significant difference in scores on the Verbal Bxpression subtest of the ITPA between the standardizing test population and that of Black children ages three years six months through six years in Portland, Oregon. The results of the 2-ANOVA indieated a statistically significant difference at the .05 level on all variables. Therefore, the null hypothesis is rejeeted for this subtest (Table VI).

\section{Table VI}

2-ANOVA FOR VERBAL EXPRESSION SUBTEST FOR KIRK'S SAMPLE AND JAMES' SAMPLE

\begin{tabular}{|c|c|c|c|c|}
\hline Source & ss & $d f$ & is & $F$ \\
\hline Chron. Age & 662.38 & 5 & 132.48 & $11.58 *$ \\
\hline Iocation & 546.02 & 1 & 546.01 & $47.73 *$ \\
\hline Interaction & 597.82 & 5 & 119.56 & $10.45^{*}$ \\
\hline Brrror & $777 \cdot 97$ & 68 & 11.44 & \\
\hline
\end{tabular}

*p $<.05$ significant 
Overall subtests performance between Kirk's sample and James' sample are graphically represented by Figure Two.

$$
\text { DISCUSS ION }
$$

\section{Mental Ages}

In the analysis of mental ages, only the mental age factor was signiflcant while location (Portland and Midwest) and interaction (combined effect of age and location on performance) were not. A possible explanation for the age factor being significant is that in normal huiban development six year olds are expected to perform better than three year olds. Since the location and interaction factors were not different, this indicates that these two samples could be from the same population based on mental ages.

SES

The goal of the SES analysis was to provide insight as to how the three SES levels correlated on the subtests. This information would help to serve as a guide in a clinical evaluation of a Black chlld's speech and language. However, only the High SES versus Low SES on the Crammatic Closures Subtest was statistically significant.

Callahan (1974) suggested that a Black child uses the language that is heard in his environment. Perhaps a conclusion that could be drawn from the results of this study is that the High SES Black children come from environments in which Standard English is used more frequently than Black English, so when confronted by the Grammatic Closure Subtest, the subject uses the model most familiar in his 
A COMPARISON" OF THE MEAN OF RAW SCORES BETWEEN KIRK' 's STANDARDIZING POPULATION AND JAMES' TEST POPULATION IN, PORTLAND, OREGON.
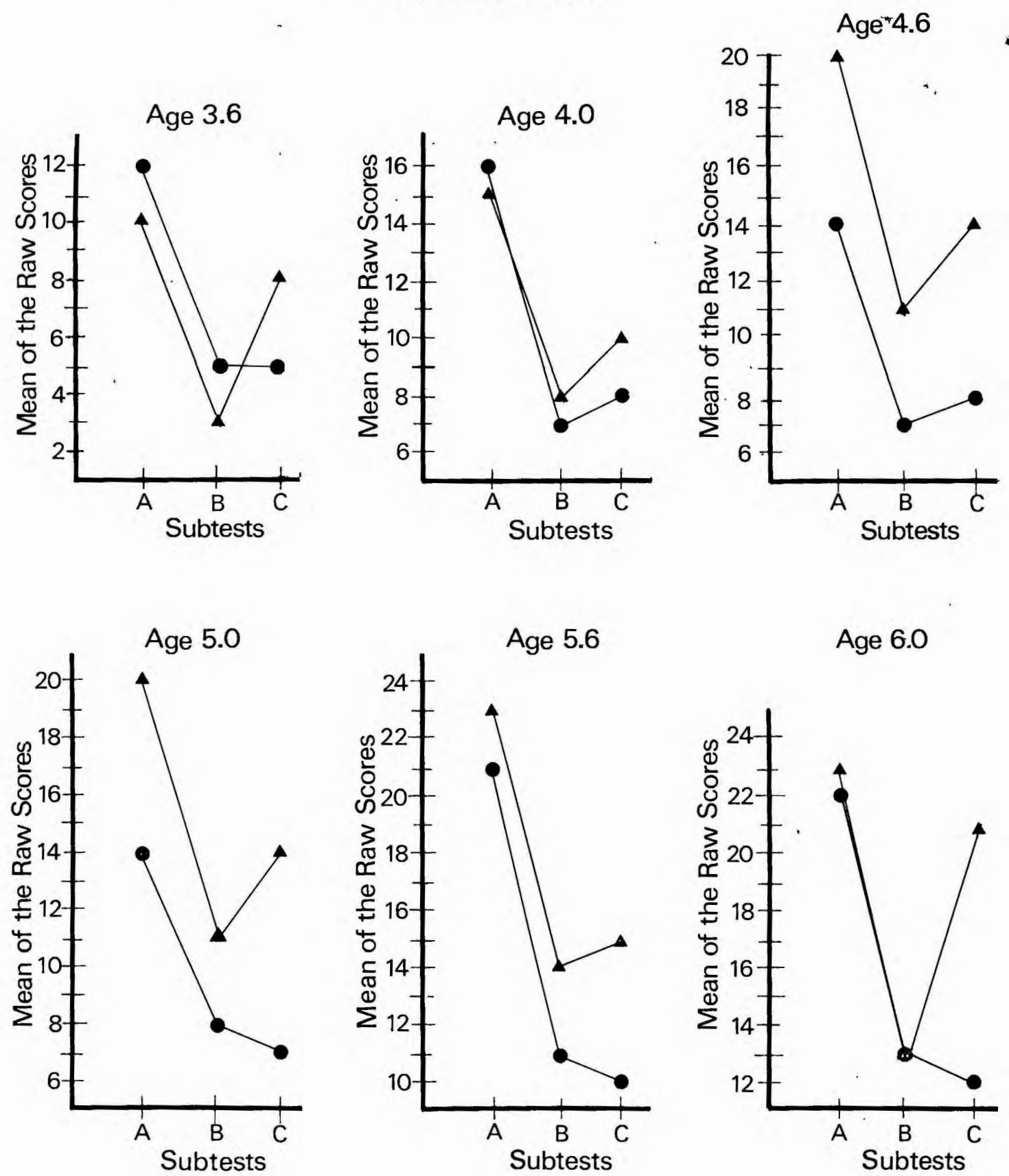

Age 6.0

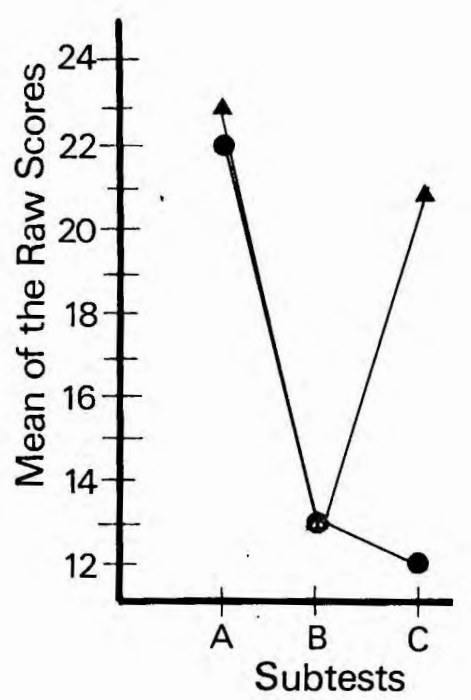
A. auditory reception
B. grammatic closure
C. verbal expression

- James' test

A Kirk's std. 
environment.

Subtests

The one factor that has remained statistically important throughout all the analysis of the various subtests has been age. This factor was discussed in the sections on mental ages. What this factor probably reveals is maturational progress which is expected as a child grows older. Therefore, for the sake of brevity, this investigator will limit the discussion to the location and interaction factors of the subtests.

Analysis indicates location and interaction were non-significant In the results obtained on the Auditory Reception Subtest. Peskin (1973) conducted a study on comprehension between Black and white children using aural-oral, and visual-reading tasks. Her results on the aural-oral comprehension tests revealed comprehension of white children was not significantly greater than black children when the tasks presented are in the aural-oral mode. The results of the Auditory Reception subtest in this study appear to conform to the results of Peskin's study (1973). A possible hypothesis that could be conjectured after reviewing the literature is that the Auditory Reception Subtest is valid for use in the evaluation of a Black child's language ability in Portland, Oregon.

Analysis of the Grammatic Closure subtest revealed that all the variables (age, location, interaction), were involved in test performance. In Kirk's sample, children from the Midwest scored higher than James' sample of Black children from Portland, Oregon, on this subtest. 
Kirk's sample also seored higher as age increased (refer to Bigure Two). Kirk and Kirk (1972) stated that "since the ITPA was standardized on mainly a Caucasion population all colloquial patterns should be noted." It has been cited in the revlew of the literature that recent research has classifled the differences tween Black and white English. Perhaps these differences of grammatical, morphological and syntactical usage could be influencing factors that affected the Black child's scores on this subtest.

Kirk and Kirk (1972) also stated that "interpretation of a low score on the Crammatic Closure subtest should take into account the language to which the child is exposed." Within every city there is some type of "inner city" whexe certain types, elasses, or races of people dwell. In the case of Black children it results in their being exposed to Black dialect more frequently in their "inner city."

Therefore, since the Grammatic Closure subtest is based on Standard Inglish patterns including such grammatical forms as plural markers and past tense, this investigator feels that unless separate norms are established for Black ehildren this subtest will not present an accurate evaluation of a Black child's grasp of the Bnglish language. Analysis of the Verbel Expression subtest indicated that Kirk's sample, children from the Midwest, scored higher than James' sample, Black children from Portland, Oregon. This analysis also indicated that in Kirk's sample scores increased with age.

Kirk and Kirk (1972), in the chapter describing guidelines for remediation for poor Verbal Bxpression performance, cite five possible 
reasons for poor performance: 1) lack of basic vocal skills;

2) lack of adequate vocabulary; 3) inability to express ideas spontaneously due to poor retrieval of words; 4) lack of automatic grammatical skills; and 5) lack of interpersonal communication skills.

Of the five possible reasons listed above, only one has been formally investigated by this study, grammar skills, in which the James' sample scored below the established white norms. It could be that the low scores on grammar skills of James ${ }^{\prime}$ sample influenced their Verbal Expression scores. It has been reported by the ITPA creators that each subtest measures a discrete aspect of language behavior. However, since grammar skills were listed as a possible Influence on verbal output, it appears that Grammatic closure and Verbal Expression performances are not separate but are interrelated. Therefore, this investigator suggests that in order for the Verbal Expression subtest to serve as an accurate assessment of a Black. child's language ability, noxmative information must be established on Black children for verbel expression.

Consideration was given to analyzing statistically Kirk's sample and James' sample on the linguistic categories of Verbal Bxpression. This idea, however, was rejected since discrete data on this subtest were not available on the forty children selected from Kirk's sample. Kirk and Paraskevoporlos (1969) did provide tatal sample performance of the linguistie categories of the Verbal Expression subtest;cconsequently, those groups that were similar in age range to the Portland age range were used in a visual comparison to assess the Portland children's linguistic strengths and weaknesses (Table VII). 


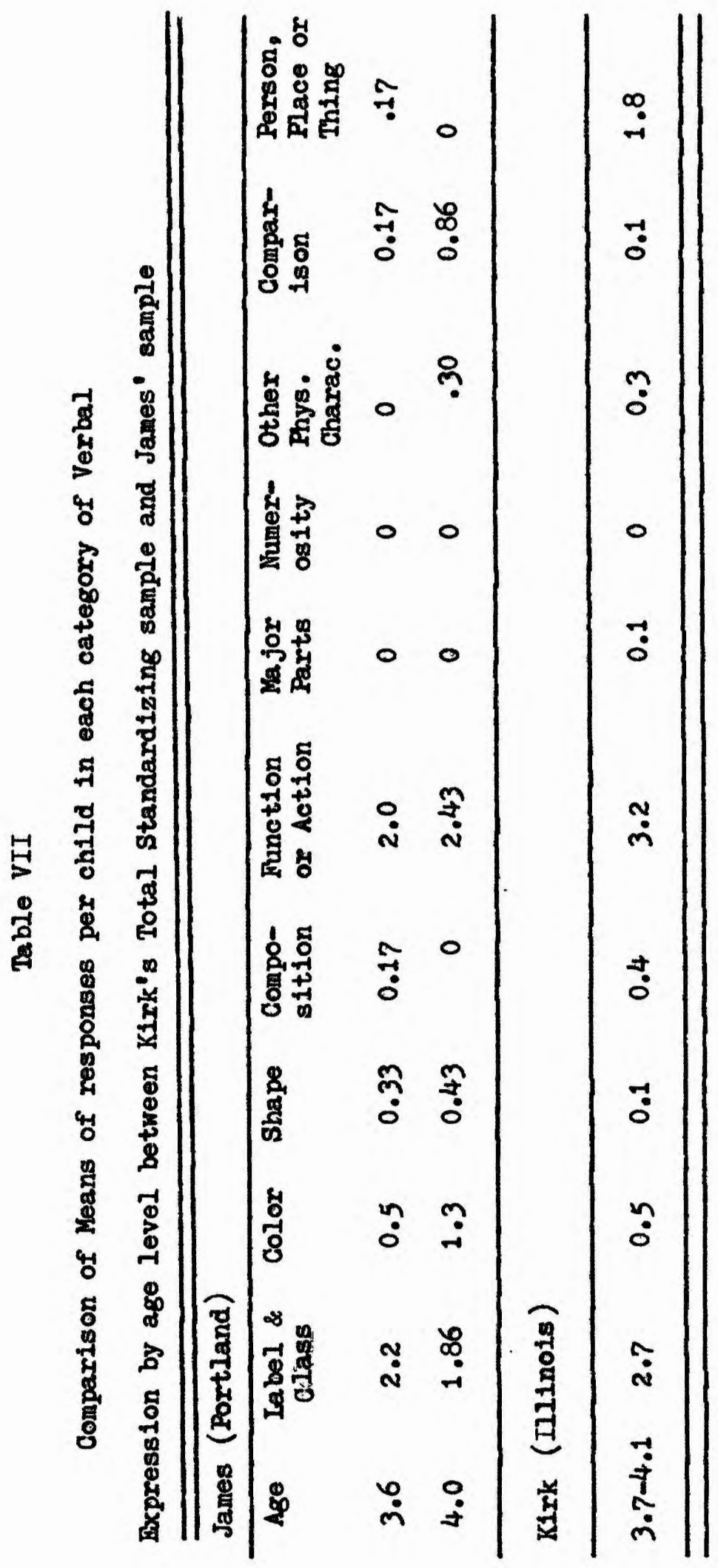




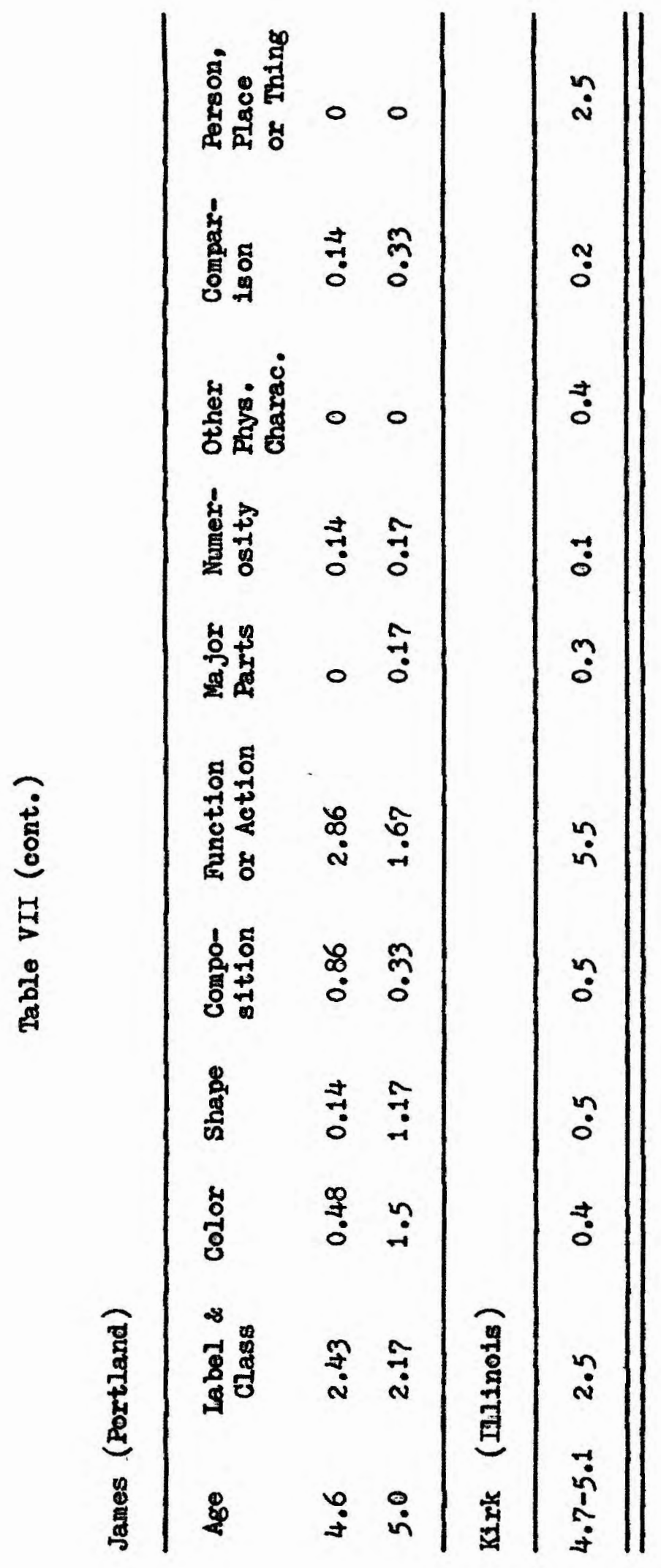




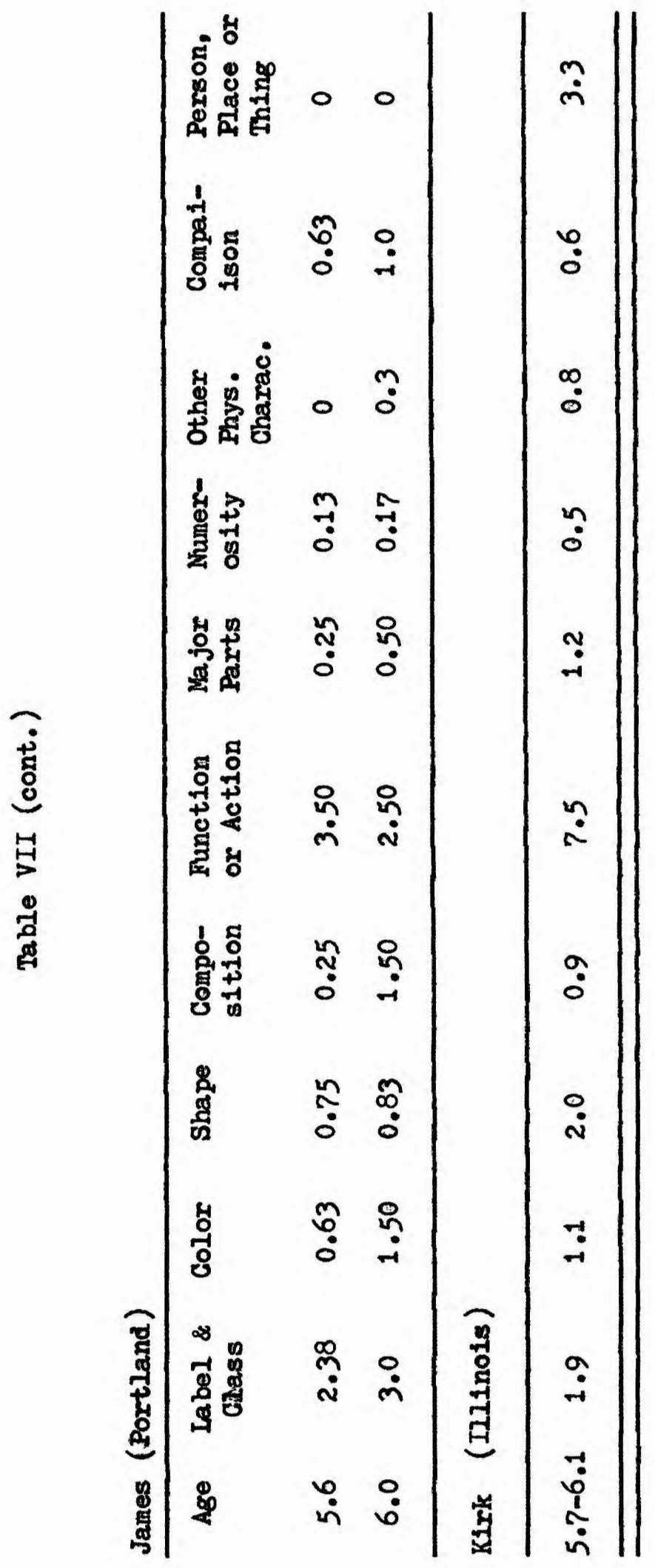


To facilitate comprehension and interpretation of the information provided in Table VII, a summary of the results of this visual inspection is presented in Table VIII.

Overall results of the linguistic categories reveal the Portland sample to be strongly lacking in: 1) identifying its function or action; 2) identifying major parts; 3) generalizing to other person, place or things; and 4) other physical characteristics. The Portland sample was moderately lacking in: 1) identifying shapes of objects and 2) identifying object composition. The Portland sample's strengths appear to vary among the categories at different age levels (refer to Table VIII).

Keller (1975) conducted an experiment including both Blacks and whites from Middle SES and IOW SES to compare response pattern to the Daberon. She reported that: 1) Blacks scored lower on identifying concepts; 2) Blacks give specific answers to tasks that can be elaborated; and 3) when comparing Blacks to whites, Blacks appear not to perform as well.

The results of the linguistic category comparison suggest that Black children in Portland, Oregon, do not give elaborated statements to concrete items on the Verbal Bxpression subtest, which results in a lower score on the test. It appears that Kirk's correct answers to the questions on Verbal Expression penalizes the Black speaker for not elaborating on the object as it has been reported in the literature that Black children tend to give restricted answers to specific questions.

Another important aspect of the present study that appears to be consistent with the research of Keller and others is that when Blacks 


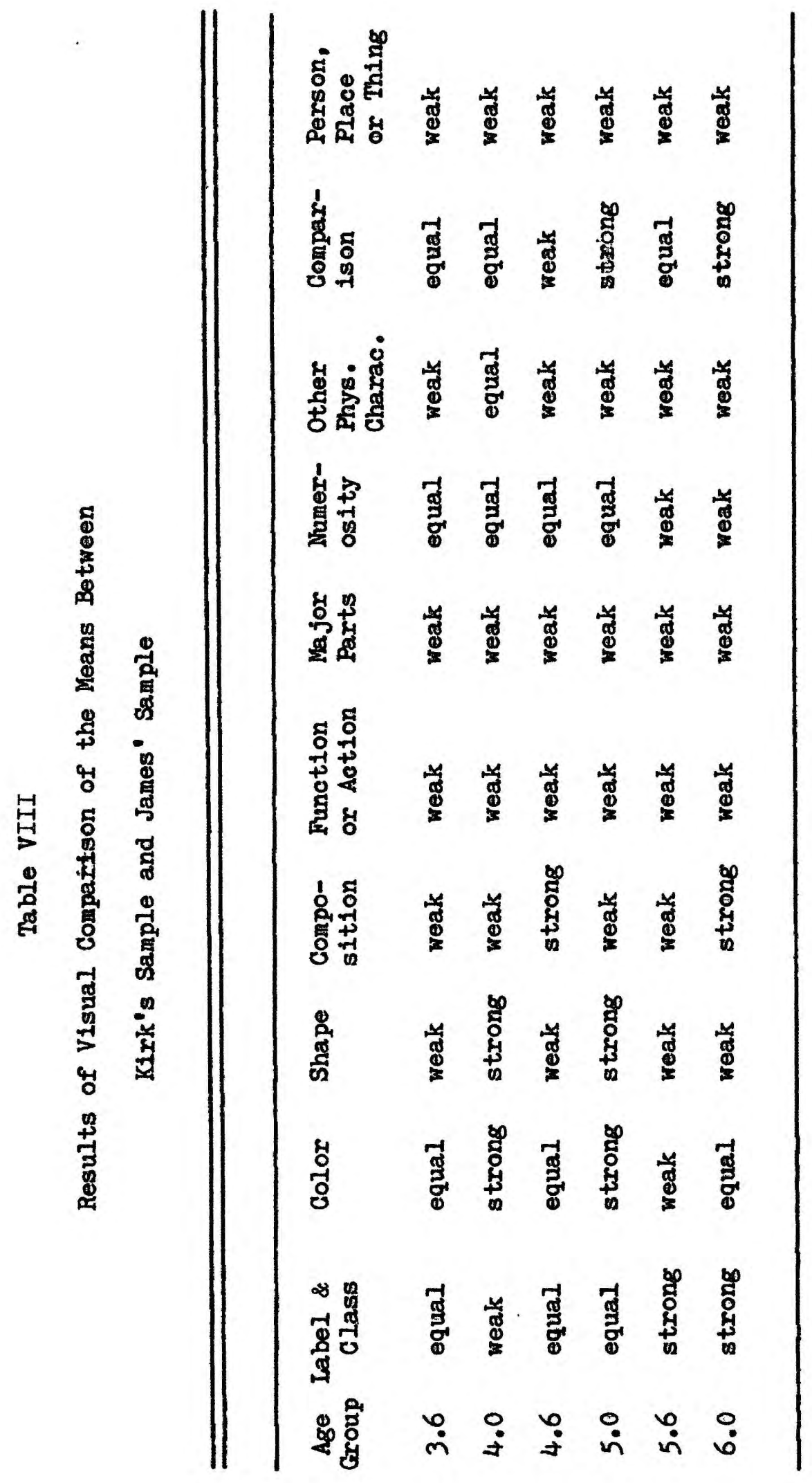

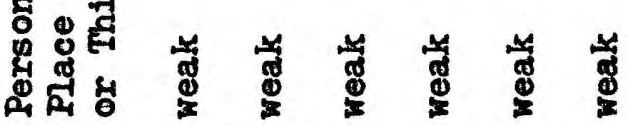

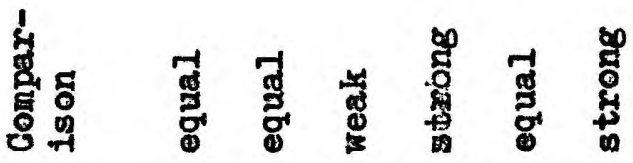

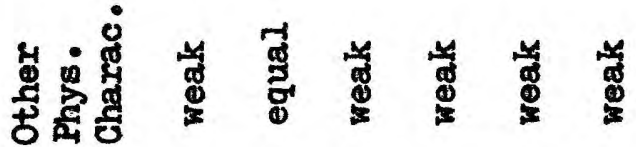

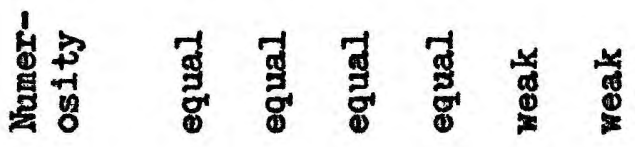

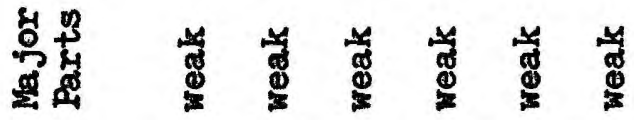

옹 옹

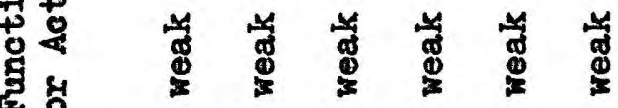

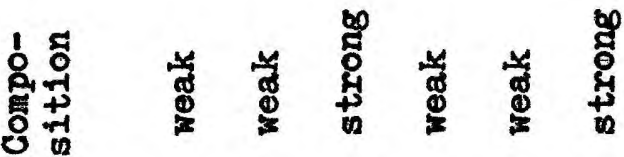

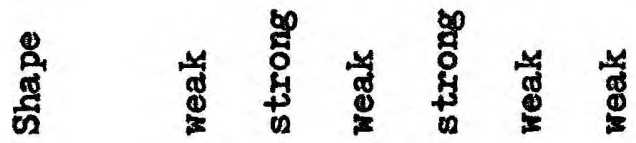

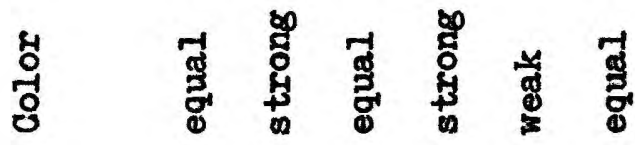

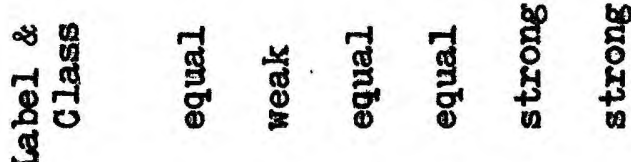

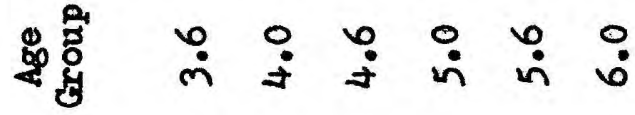


are compared to whites they appear to do poorly. The results of this more indepth investigation of the Verbal Expression subtest demonstratessa need for the establishment of Black norms for the subtest. This investigator is of the opinion that without specifie norms for Black children, the speech clinician's diagnoses and evaluation of Black children will continue to reflect a misleading score due to the comparison of white norms. 
CHAPTER V

SUMMARY AND IMPLICATIONS

\section{SUMMARY}

The purpose of this project was to investigate language performance of Black children ages three years six months to six years in Portland, Oregon, on three subtests of the Illinois Test of PsychoIinguistic Abilities (ITPA) (1972), Crammatic Closure, Auditory Reception, and Verbal Expression. Forty Black children were randonly selected from three day care centers and one elementary school in Portland, Oregon. All children were screened and tested by the investigator who was of the same ethnic background as the subjects.

The results of this study indicated that the subjects in Portland, Oregon, demonstrated language abilities similar to the ITPA normative group in the Midrest on the Auditory Reception subtest. These same Portland, subjects, however, demonstrated a difference in language abilities from the normative group in the Midwest on the subtests of Grammatic Closure and Verbal Expression. On these two subtests the Midwestern children obtained significantly higher scores than the Portland children.

An explanation for the results in this study might be that Black children may have used a Black language model to construct a Standard English sentence. In addition, it may be that, just as there are regional dialect differences, there could be regional language 
differences as well.

The only difference accounted for by SES was the higher performance on Crammatlc Closure subtest by High SES group. SES apparently did not affect the other two subtests.

The results obtained by this study offer support for the establishment of normative information on the Black population in Portland, Oregon.

\section{IMPLICATIONS}

\section{Practical}

To the speech and language student or cliniclan who used the ITPA as a diagnostic or evaluative instrument with Black children, the results of this study offers validity to the results obtalned with the Auditory Reception subtest. Caution should be used, however, in interpreting the results of a Black child's performance on the Grammatic Closure and Verbal Expression subtests.

According to the results obtained by this study, these two subtests, Grammatic Closure and Verbal Expression, appear to penalize the Black child whose major source of language learning is with Black English. It also penalizes the Black child who gives specific replies to ppen-ended terminology of the Verbal Expression subtest. This investigator encourages the speech and language clinician to become familiar with the language and cultural patterns of Black speakers in their region to aid in their clinical evaluation. 
Future Research

If future research is conducted the author suggests that: 1) a similar study be conducted using a white speech elinician; 2) a direct age match with Kirk's standardiging population and with more children enlisted; and 3) that a study bo conducted using the complete ITPA with Black children with both Black and white examiners. 


\section{BIBLIOGRAPHY}

Ammon, Paul, R., Symtactic Hlobration in Speech of Lower-Class Blacks and Middle Class White Preschool Children. (Bethesda, Md. 8 Eric Document Reproduction Servicer ED081493, 1973).

Anastasiow, Nicholas, and Hanes, Michael, Language Reconstructions as an Indicator of Cognitive functioning of K-Third Graders. (Bethesda, Md. 8 Bric Document Reproduction Servico, ED099100, 1974).

Anderson, A., and Novina, J. A study of the tests of central auditory abilities and the ITPA. Journal of Language Disorders, V. 16, 167-169 (1973).

Baratz, Joan, Teaching Black Children to Read. (Bethesda, Md.: Fric Document Reproduction Service, EDO25761, 1969).

Baratz, J. Language and cognitive assessment of Negro childrens. assumption and research needs, ASHA, Vol. 11, No. 3, 87-91, March, (1969).

Baratz, J., and Baratz, S., Negro Ghetto Children and Urban Education: A Cultural Solution, Florida Reporter, Vol. 7, 11-14 (1964).

Baratz, J., Teaching reading in an urban Negro school system. In F. Williams, ed., Ianguage and Poverty. Chicago: Markham Publishing Company, (1972).

Bartel, N.R., et al, Language Characteristies of Black Children: Implications for Assessment. Journal of School Psychology, 11. $351-364,1973$.

Beatty, Walcott, (Bd.), Improving Educational Assessment and An Inventory of Measure of Affective Behavior. (Bothesda, Md.: Bric Document Reproduction Service EDO34730, 1969).

Bereiter, C., Academic instruction and preschool children. In R. Cobin and M. Crosby, eds., Language Programs for the Disadvantage. Champaign, Ill.: National Council of Teachers of English, (1965).

Bernstein, B., A sociolingiistic approach to socialization with some referent to educatability. In F. Williams (ed.), Language and Poverty. Chicagos Markham Publishing Company (1972).

Berry, M. Language Disorders of Children, The Bases and Diagnosis. New York: Appleton-Century=Crofts (1969).

Beyer, W., (ed.), Handbook of Pables for Probability and Statistics. Ohios The Chemical Rubber Co. (1966). 
Bryant, Edward, C., Statistical Analysis, McGraw Hill Company, New York, Chapter 11, Second edition.

Burling, R. English in Black and White. New Yorks Holt, Rinehart and Winston, Inc. (1973).

Callahan, Nargaret, An investigation of the influenoe of dialectal interference on the NSST scores obtained by Poxtland Black children. Unpublished Masters Thesis, Portland State University (1974).

Casteel, Robert, Quote from Classnotes at Portland State University, Unpublished (1974).

Cicirelli, V., et. al., Performance of disadvantage primary-grade children on the revised ITPA, Psychology in the Schools. Vol. 8 , $240-241$ (1972).

Cline, Marvin, Stanford-BInet, PPVT, and Low-Income Preschoolers : New Pltfalls for Old Tests. (Bethesda, Md.: Fric Document Reproduction Service ED059274, 1966).

Cochrane, K., Common sense and remedial teaching. The Slow Learning Child. 17, 144-148, (1970).

Cochran, K., et. al., Current Development in the Assessment of Language, and Its Uses in Educational and Clinical Situations, SIow Learning Child, 153-164 (1972).

Cole, Kevin, A comparison and item analysis of responses between Black children and language delayed white children on the Peabody Plcture Vocabulary Test. Unpublished Masters Thesis, Portland State University (1975).

Deese, James, Psychollnguist1cs. Boston, Mass. Allyn and Bacon, Inc. (1970).

Dobzhansky, Theodosius, Differences are not deficits. Psychology Today, Vol. $17.97-100$ (1973).

Englemann, S.. How to construct effective language prograns for the poverty child. In F. Williams, ed., Ianguage and Poverty. Chicagos Narkham Publishing Company, (1972).

Bvard, Beth, and McGrady, Harold, Development of Local Language Norms for Papago Indians, Mexican-Americans, Blacks and Anglos. (Bethesda, Md.: Eric Document Reproduction Service Fd105732, $(1974)$.

Fasold, R., and Wolfram, W., Some linguistic features of Negro dialect, ISHSS, Vol. 3, No. 4, 16-49, October (1972). 
Garcia-Zamore, M., and Krowitz, Mary, Contextual Testing and Communication Competence. (Bethesda, Md. 8 Bric Document Reproduction Service, ED104145, 1974).

Garrey, C., and McFarlane, P. A preliminary study of standard English speech patterns in the Beltimore City Public Schools. (Bethesda, Md.: Fric Document Reproduction Service, EDO19265, 1968).

Gerpta, W, and Stern, C. Comparative effectiveness of speaking vs. Iistening in improving spoken language of disadvantaged young children. Journal of Experimental Education, 38, 54-57, (1969).

Gerstman, L. Quote from Classnotes at City College of New York, Unpublished (1973).

Gordon, Mary, Quote from Classnotes at Portland State University, Unpublished (1975).

Hallett, Suzanne, Over-Bxtension Phenomena in Children's Acquisition of Spatial Adjectives. (Bethesda, Md.: Eric Document of Reproduction Service, EM00163, 1974).

Harris, D. Children's Drawings as Measures of Intellectual Maturity, Hareourt, Brace and World, Ine.s New York (1963).

Hopper, Robert, and Naremore, Rita, Children's Speech, A Practical Introduction to Communication Development. New York, Harper and Row, Publishers (1973).

Houston, David, A Comparison of Written Compositions of Head-Start Pupils with Non-Head Start Pupils. (Bethesda, Md.: Bric Document Reproduction Service, EDO47204, 1969).

The Impact of Head Start. Vol. 1, Columbus, Ohio Vestingtonhouse Learning Corporation and Ohio University, (1969).

Jensen, A., The differences are real. Psychology Today, Vol. 7, 80-86 (1973b).

Keller, Margo, A comparative study of responses by varying socioeconomic groups on general knowledge and categorization tasks. Unpublished Masters Thes1s, Portland State University, (1975).

Kirk, Samuel, Bthnic difference in psycholinguistic ability. Exceptional Ch1ldren, 39, 112-119, (1972).

Kirk, Samuel, and Kirk, W., Psycholinguistic learning disabilities diafnosis and remediation. Urbana, IIIinols; University Press, (1972). 
Kirk, S., and Paraskevoporlos, J., The development and psychometric characteristics of the Revised Illinols Test of Psycholinguistic Abilities. Chicagos University of Illinois Press, (1969).

Labov, W., Language characteristies: Blacks, In R. Bently and S. Crawford, eds., Black Language Reader. Glenview, Illinois: Scott, Foresman and Company, (1973).

Iabov, W. The logic of nonstandard Bnglish, In F. Williams, ed., Ianguage and Poverty, Chicago: Markham Publishing Company (1972).

Iangacker, Ronald, Ianguage and Its Structures Some Fundamental Linguistic Concepts. New York: Harcourt, Brace and World, Ine., (1968).

Iarton, S., The comparison of one teacher's oral language assessment and a panel of experts' oral language assessment of ten Blacks. (Bethesda, Md.: Fric Document Reproduction Service, ED081866, 1973).

Lawton, D., Social class difference in language development, a study of some samples of written work. Ianguage and Speech, 6, 120-143, (1963).

-..--., Social class language difference in group discussion. Ianguage and Speech, 17, 183-204, (1964).

Iee, Laura, A screening test for syntax development. JSHR, 31 , 311-330, (1970).

Lerea, I. Assessing language development, JSHR, Vol. 1, 75-85 (1958).

Leventhal, Donald, and Stedman, Donald, A Factor Analytic Study of the Performance of 340 Disadvantaged Children on the IIlinois Test of Psycholinguistie Abilities. (Bethesda, Ma.: Fric Document Reproduction Service, EDO44438, 1967).

Levy, Betty, Dialect Profleiency and Auditory Comprehension in Standard and Non-Standard English. (Bethesda, Md.: Bric Document Reproduction Service, 1972).

Malloy, M., The Black kids burden. The National Observer, 1-18, November 15 (1975).

McFrroy, C., Speech and Lenguage Development of the Preschool Ch1lds A Survey. Springfleld, IIlinois: Charles C. Thomas, (1972).

McCarthy, James, and Olson, JJames, Validity Studies on the Illinois Test of Psycholinguistic Abilities. Urbana: University of IIlinois Press, (1964). 
McNe111, David, Developmental psycholinguistics. In The Cenesis of Ianquaze: A Prycholinguistic Approach. Smith, F., and Miller, Ceorge, (Eds.), Cambridge, Kass . M.I.T. Press, (1966). ,

NoNe11, Elton. The Psychology of Being Human. San Franciscos Canfield Press, (1974).

MePha1l, Irving, Teaching Black Children to Read: A Review of Psychoand Sociolinguistic Theorles and Models. (Bethesday, Md.: Eric Document Reproduction Service, EM03819, 1974).

Messick, Samuel, Beyon structure: In search of functional models of psychological process. Psychonetrik, 37, 457-474, (1972).

Monsees, Edna, and Berman, Carol, Speech and language screening in a summer headstart progran. JSHD, 33, 121-126, (1968).

Myklebust, H., Development and Disorders of Written Language. In Senders, Evaluation of Speech and Ianguage Disorders in Children. Danville, Illinois: Interstate Printers and Publishers, (1972).

Newcomex, P.. and Hamill, D. Psycholinguistic in the Schools, Charles Morrill Publitshing Company, Columbus, Oh1o (1976).

Pasamanick, B., and Knobloch, H., Rarly language behavior in Negro children and the testing of intelligence. Journal of Abnormal Social Psychology. 50, 401 402 (1955).

Perkins, A., Speech Pathology: An Applied Behavioral Selence. St. Louis: C.V. Mosby Co. (1971).

Peskin, M. Interaction of Dialect, SES, Ethnicity Upon Iistening and Reading Comprehension of Flfth Graders. (Bethesda, Md : Bric Document Reproduction Service, ED)85691, 1973).

Phillips, Judith, The Fffects of the Examiner and the Testing Situation Upon the Performance of Culturaliy Deprived Children. Phase I-Intelligence and Ianguage Ability Test Scores as A Function of the Race of the Examiner. (Bethesda, Md.: Eric Document Reproduction Service, EDP11963, 1966).

Poole, Millicent, Social class and code elaboration in written communication, Australian Journal of Edueation, 15, 1-7, (1971).

Ratusnik, David, and Koenigsknecht, Roy, Drawing Test Performance of Black and White Preschoolers as a Function of Biracial Testing. (Bethesda, Ma. Fric Document Reproduction Service, ED107340, 1975).

Reeker, Iarry, A problem solving theory of syntax acquisition. Journal of Structural Learning, 12, 1-10, (1971). 
Robinson, H., and Mukerjl, R., Ianguage concepts and the disadvantaged. Educational Ieadership, 23, 133-141, (1965).

Rosenthal, R., Self-fulfilling Propheey, Psychology Today, 2, 46-51, (1968).

Rosenthal, R., and Jacobson, R., Teacher expectation for disadvantaged. Scientiflc American, 218, 19-23, (1968).

Ryan, B. and Gray, B., A Ianquage Program for the Non-Ianguage Child. Illinois: Research Press, (1973).

Ryokman, D.B., The psychological processes of disadvantaged children. Doctoral dissertation, University of IIIinots, (1966).

Samuda, Ronald, Psychological Testing of American Minorities: Issues and Consequences. New York Dodd, Mead and Company, (1974).

-m.n-. Racial Discrinination Through Mental Testing: A Social Gritic's Vier. (Bethesda, Ma.: Eric Document Reproduction Service, EDP92648, 1973).

Saunders, I., Evaluation of Speech and Ianguage Disorders in Children. Danvilie, Illinois: Interstate Printers and Publishers, (1972).

Severson, Roger and Guest, Kristin, Toward the Standardized Assessment of the Ianguage of Disadvantage Children. In Ianguage and Poverty, 96-98, (1974).

Seymor, Dorothy, Black children, Black speech, Commonweal, 175-178, November (1971).

Slobin, Dan, Psycholinguistic, Glenview, Illinois: Seott, Foresman and Company (1971).

Stephenson, B.. An investigation of the psycholinguistic abilities of Negro and thite children from four socloeconomic status Ievels (Bethesda, Md.: Eric Document Reproduction Service, EDQ41261, 1970).

Stephenson, B. and Cay, H., Psycholinguistic abilities of black and white children from four SES levels. Exceptional Children. . 38. 705-709 (1972).

Taylor, Orlando, An introduction to the historical development of Black Anglish: some implications for American education, ISHSS, Vol. 3. No. 4, 5-15, October (1972).

Travis, Iee, (ed)., Handbook of Speech Pathology and Audiology. New York: Appleton-Century-Crofts (1971). 
Weaver, J. and Weaver, A., Fycholinguistic Abilities of Culturally Deprived Negro Children. AJMD, 72, 190-197 (1967).

Williams, F. (ed.), Ianguage and Poverty, Chicago: Markham Publishing Company (1972).

Williams, R., A linguistic description of nonstandard Inglish. A paper presented at ASHA, (1972).

Williams, S., Continuity and change in American Negro dialects. In R. Bently and S. Crawford (eds.) Black Ianguage Reader. Glenview, Illinois: Scott, Foresman and Company (1973).

Williams, S., Toward a history of American Negro dialect. In F. Wililians (ed.), Language and Poverty. Chicago: Markham Publishing Company (1972).

Wolfram, W., Sociolinguistic premises and the nature of non-standard dialects. An A. Smith (ed.), Ianguage, Communication and Bhetoric in Black America. New Yorks Harper and Row, (1972).

U.S. Bureau of the Census. Methodology and Scores of Socioeconomic Status, Working Paper No, 15. Washington, D.C., (1963).

Zelditch, M., A Basic Course in Sociological Statistics. New Yorks Hoit, Reinhart and Winston, (1959). 


\section{APPENDIX A}

SURVEY OF LANGUAGE TESTS USED IN PORTLAND, OREGON FOR ILANGUAGE DISORDER DIAGMOSIS (June, 1975)

Assessment of Children Ianguage Comprehension ....... 4

Ammons \& Ammons Full Range Plcture Vocabulary Test ..... 2

**Boehr Test of Basic Concepts ............. 17

Carrow's Test of Auditory Comprehension .......... 1

* Daberon School Readiness Device ............. 19

Denver Development Language Test ........... 2

Preschool Speech and Ianguage Screening Test ... . . . 1

Frostig Inventory ................. 1

Hills boro Informal Inventory for ages 4 through $7 \ldots$..... 1

Houston Test for Ianguage .............. 3

**Illinois Test of Psycholinguistic Abilities . . . . . . 8

Katz's Audttory Test ................. 2

Kindergarten Auditory Screening Test ......... 3

L.A. Inventory .............. 3

Language Disorder Screening Tool ............. 1

Ianguage Sample $(K L R)$............... 4

Iaura Iee's Developmental Sentence Scoring ........ 4

Ieiten ........................... 1

Iindamood Auditory Conceptualization ......... 3

MeCarthy ........................ 3

Miller-Yoder Language Comprehension Test ........ 2 
**Northwest Syntax Screening Test . . . . . . . . . . 11

* Peabody Plcture Vocabulary Test .............. 21

**Programmed Conditioning for Ianguage Test . . . . . . 13

Receptive Bxpressive Buergent Ianguage . . . . . . . 3

Screening Analysis for Educational Needs ......... 1

Sequenced Inventory of Ianguage Development ........ 4

slossen .......................... 1

Templin Darley . . . . . . . . . . . . . . 2

University of Oregon's C.C.D. Language Manual . . . . . 6

Utah Test for Ianguage ................. 6

Wepman Discrimination .................. 1

W.I.S.G. Vocabulary Subtest ................ 1

Wide Range Achievement Test . . . . . . . . . . 2

TOTAL TESTS - 35

**Six most popular tests in usage. 


\section{APPENDIX B}

\section{Iinguistic Features of Black Bialect*}

\section{Syntactic Features}

1) The expression of possession is different. Standard Bnglish: "Joe's pencil", Non Standard Dialects "Joe pencll."

2) Negation is expressed by double negatives or "ain't." S.E.: "I don't have a peneiI"; N.S.s "I ain't got no pene1l."

3) Subject-verb agreembnt differs. S.E.8 "We were there" or "They are here"; NSI.8 "We was there" or "They is here."

4) "S" is omitted from third-person singular verbs in the dialect. "He sings" becomes "He sing."

5) The use of "is" is not necessary in present tense sentences. "I am going" or "He is here" becomes "I going" or "He here."

6) "If" constructions are changed. "I'll ask Mary if she wants to go" may be changed to "I'II ask Mary do she want to go."

7) The "ed" on past tense verbs may be omitted. "He walked" may become "He walk." (Note, Irregular past tense will not be onitted).

8) Future tense of verbs may be expressed differently. "I'm going to g0" will be "I'm a go." "He's going to go" will be "He 'gon go."

9) "Be" may be used to express habitual action. "He be sick" means "He's always sick" as opposed to "He sick" meaning "He's sick right now."

10) Pronominal apposition will appear in the subject of a sentence. "John is funny" will be "John he funny." 
Phonological Features

1) " $r$ " may be omitted before consonants or if it is the last sound in a wora.

2) "I" may be omitted before consonants of if it is a final sound.

3) Consonant clusters at the end of words will be shortened. "First will be "firs" and ltoid" will be "tol."

4) Final consonants will be weaker. "Want" will sound like "wan".

*Hopper \& Naremore, Children's Speech 


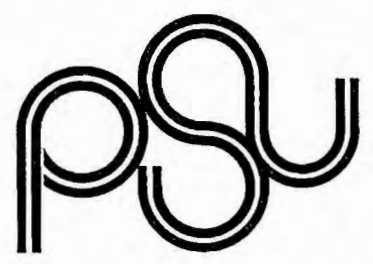

Dear Parent:

Your child has been selected to participate in a research project to establish normative language tables for Portland, Oregon.

The research project is being conducted by George James, a Black graduate student at Portland State University.

Your child will be given a screening test for hearing, three. language tests and a Draw-a-man test. This should take approximately 45 minutes to one hour.

If you feel you would like to help in establishing these tables, which hopefully will lead to better educational services for children, please sign and fill in the enclosed questionnaire and permission silp.

The questionnalre is to help in establishing different groups for analysis in this study.

You will recelve a phone call from George James, in the early part of the evening, between 6-8 p.m. to answer any questions you may have.

Thank you for your consideration and cooperation in this study. Sincerely yours,

George E. James Graduate Student 


\section{PERMISSION SIIP}

I being the parent(s) or

guardian(s) of hereby grant permission for my son/daughter to participate in George James' research project. I understand he will administer an auditory $s$ screening task, the Goodenough-Harris Draw-a-Man test, and the Gramatic Glosure, Verbal Expression, and Auditory Reception subtests of the Illinois Test of Psycholinguistic Ability. I also understand that all information is confidential and no names will be used.

Signature of Parent(s) or Guardian(s) 
APPENDIX D

QUESIONANAIRT FOR DETERMTNING SES

Research No.

Head of Household. Place an X on the line that applies to you.

a. Wife

b. Husband

Head of Household's Occupation

Company

Position Held

Income Range (per Year). Place an X on the line that describes your income range.
a. under 3,000
8. $8,500-9,000$
b. $3,500-4,000$
h. $9,500-10,000$
c. $4,500-5,000$
1. $10,500-11,000$
d. $5,500-6,000$
j. $11,500-12,000$
e. $6,500-7,000$
k. over 12,500
f. $7,500-8,000$

Total years of education. Place an $X$ on the line that describes your educational level.

Self Elementary Hus band:

Junior High

High School

Technical School

College: 1

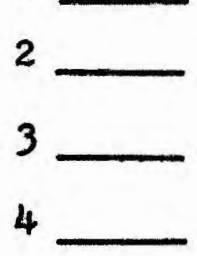

